\title{
SOCIALLy OPTIMAL RoyALTY DESIGN AND Illegal LogGing Under Alternative PenAlty SCHEMES
}

\author{
GREGORY S. AMACHER \\ ERKKI KOSKELA \\ MARKKU OLLIKAINEN
}

CESIFO WORKING PAPER No. 1131

CATEGORY 1: PUblic FinANCE

FEBRUARY 2004

\footnotetext{
An electronic version of the paper may be downloaded

- from the SSRN website:

www.SSRN.com

- from the CESifo website:

www.CESifo.de
} 


\title{
SOCIALLY OPTIMAL RoyALTY DESIGN AND ILLEGAL LOGGING UNDER ALTERNATIVE PENALTY SCHEMES
}

\begin{abstract}
We study the socially optimal design of forest royalty and enforcement instruments in the case where concessions are allocated by a government, illegal logging incentives are present, and the government has available both area-based and value-based royalty instruments. When harvesters are risk neutral, the optimal policy mix depends on the presence of negative externalities and on the type of penalty scheme. For risk-averse harvesters the results differ. When the penalty is assessed on undeclared income, a royalty based subsidy is not optimal, but when penalties are levied on evaded royalty payments, the optimal royalty system may be progressive or regressive depending on the importance of the government's revenue constraint. Auditing is optimal regardless of the penalty scheme or presence of externalities, although its level differs. Accounting for negative externalities in the social welfare function implies a higher optimal royalty rate, but lower progression in the rate, and increased auditing.
\end{abstract}

Keywords: illegal logging, royalty design, penalty schemes.

JEL Classification: D81, H26, Q21, Q23.

Gregory S. Amacher
Department of Forestry, College of Natural
Resources, 307 Cheatham Hall, Virginia
Polytechnic Institute and State University
Blacksburg,VA 24060
USA
gamacher@vt.edu

Markku Ollikainen

Department of Economics and

Management

P.O. Box 27, FIN-00014

University of Helsinki

Finland

markku.ollikainen@helsinki.fi

\author{
Erkki Koskela \\ Department of Economics \\ P.O.Box 17, FIN-00014 \\ University of Helsinki \\ Finland \\ erkki.koskela@helsinki.fi
}




\section{Introduction}

In most of the countries with tropical forests, concessions are the primary means by which government-owned native forests are harvested (Walker and Smith 1993, Gray 2000). Policy makers sometimes view concessions as a means for providing stable wood flows to domestic forest industry (Verissimo et al. 2002). Royalties, or fees, charged for harvesting concessions provide large sources of funds to many developing country governments (Gray 2000, Amacher et al. 2001). Witness Brazil, which is about to open up over 70 million hectares of public Amazon forests for concessions, with a cited purpose being the generation of government revenues through fees attached to the concessions and sustainable forest harvesting for timber concerns (MMA 2001).

Despite the importance of royalty systems, the principles of socially optimal instrument design have not been considered. This is an important omission given the problems that are known to exist with these systems. For example, countries with distant forest concessions and inefficient centrally-located governments have difficulty containing illegal logging (a main component of tropical deforestation). There is also an inability, and sometimes unwillingness, of governments to enforce and penalize such acts even when detected (e.g., see Clarke et al 1993 for a discussion of lack of monitoring of harvest activities in developing countries, and Palmer 2000). As a result concession harvesting is usually inconsistent with parameters specified in contracts made between a government and harvesters. Illegal logging and underreporting of harvest income undermine a government's ability to implement royalty systems. Both may also increase negative externalities from deforestation and unnecessarily increase net rents to harvesters (ITTO 2002, Repetto and Gillis 1988). It has also been argued that current royalty rates in developing countries are far too low, providing little incentive to curb excessive harvesting (Gray 2000, Vincent 1990, Merry et al. 1998). Moreover, poorly-designed royalty systems have been linked to incentives for illegal logging (Palmer 2000). ${ }^{1}$

\footnotetext{
${ }^{1}$ Royalties and logging behavior have been studied recently. Vincent and Boscolo (2000) analyze the impact of royalties on use of improved logging practices, such as reduced impact logging and diameter limits. Their results are simulation-based and royalty/auditing choice and the possibility of illegal
} 
In this paper we develop benchmark results for the socially optimal design of forest royalty and enforcement instruments. We assume that concessions are allocated by a government, and that harvesters have incentives to illegally log within the concession. Illegal logging is introduced as either excessive volume removal or logging beyond the concession boundary. Illegal logging is not detectable by the government unless costly enforcement is employed, and even with enforcement the government can detect illegal logging with a probability less than one. Detection occurs through auditing, and the cost of auditing represents the enforcement efficiency of the government. Should the government detect illegal logging, we allow for one of two penalty schemes, both of which mimic penalties currently used in practice: a fine collected on undeclared (unreported) harvest income, or a fine collected on evaded (non-paid) royalty payments. ${ }^{2}$ We consider two types of royalties common in practice and the literature, concession area-based royalties and harvest value- or volume-based royalties. We allow these to also be used in combinations, making the royalty system progressive or regressive in the sense that the average tax rates are either increasing or decreasing in the taxable base.

While there are several political economy discussions of concessions each based on its own empirical peculiarities, no one to our knowledge has stepped back and evaluated the benchmark theory behind a benevolent dictator that chooses these instruments to maximize social welfare and generate rents and revenues. Obviously, we need this benchmark before we evaluate specific cases from a political economy point of view. To this end we evaluate two questions of optimal policy design, first, how do incentives for harvesters to illegally log depend on auditing effort and royalty choices, among other parameters?, and, second, how should a policy maker choose royalties and audit frequencies to provide the efficient level of rents to harvesters and amenities provided by native forests? We find that illegal logging, negative externalites

\footnotetext{
logging and penalties are not considered (they do acknowledge the potential difficulties of monitoring logging, however). Clarke et al (1993) examine the role of penalty schemes and optimal dynamic enforcement expenditures for an open access forest situation by considering a Nash game between authorities and forest poachers, where detection of illegal logging leads to prosecution. Walker and Smith (1993) model noncompliance of loggers facing a given concessions contract, and they formulate a type of auditing procedure that can limit noncompliance. But the choices of royalty and auditing policies from the perspective of a government, under revenue constraints and illegal logging incentives for harvesters, are not examined in this collection of work.

${ }^{2}$ This idea is related to literature on tax evasion, see e.g. Cowell (1987) and Myles (1995) for surveys.
} 
from a social welfare point of view, penalty schemes, and risk preferences of harvester, factor importantly in instrument design, serving to make the choice of royalties much more complicated than what is usually assumed. Solutions to deforestation are not as simple as raising all royalty fees or shifting more resources toward enforcement of concessions contracts. Rather, royalties and auditing must be designed as a system and not considered, as they often are, as separate instruments. In some rare cases, a social welfare maximizing government may never find it optimal to either eliminate illegal logging or enforce penalties under some conditions. In other cases the optimal royalty system may be progressive or even regressive, as a combination of area-based and value- or volume-based royalties. The appropriateness of progressivity has not been part of the policy debate, but our results suggest it should be.

The rest of the paper is organized as follows. In section 2 we present a simple model how illegal logging depends on penalty schemes, audit strategies and royalties, and risk attitudes of the harvester. In section 3 we study socially optimal royalty and auditing design for a risk neutral harvester when negative externalities are either present or absent. We extend this analysis in section 4 for the case of risk-averse harvesters. The last section contains our conclusions.

\section{A Basic Model of Illegal Logging}

Consider a concessionaire (i.e., harvester) who receives a permit to harvest a concession. Suppose that the harvester receives a right to harvest some amount $Q=\bar{Q}$. We will interpret this as volume throughout the paper. Governments normally impose royalties, or fees, for these harvest rights. We consider two common forms of royalties, a harvested volume- or value-based fee denoted by $t$, and an area-based royalty subsidy or fee denoted by $I$. The royalty rate $t$ is often assessed against the value permitted for harvesting, $t q \bar{Q}$, where $q$ is the timber price. This value-based interpretation is the one we will use for $t$. We allow the area-based royalty to be either a net fee or a net subsidy - we show later how this distinction is important to instrument design. Combinations of royalties are common. Usually, with either area- or value-based royalties, some quantity of harvest volume or benefit is exempted from the fee paid by the harvester. 
The way we define area- and value-based royalties mimics most systems found in developing countries with concessions, such as Indonesia, The Philippines, and Latin America, as pointed out in Gray (2000), Amacher et al. (2001), and Vincent (1990).

If the harvester does not engage in illegal activities, then the exact amount permitted in the concession is logged, and the harvester earns rents equal to,

$$
\pi=q \bar{Q}(1-t)-c(\bar{Q})
$$

where $c(\bar{Q})$ is a convex cost of harvesting, i.e. $c^{\prime}(\bar{Q}), c^{\prime \prime}(\bar{Q})>0 .^{3}$ If the harvester's rent is positive at $\bar{Q}$, i.e., if $q(1-t)-c^{\prime}(\bar{Q})>0$, then there is an inherent incentive for illegal logging. Given that forest concessions are not constantly observed by the government, there is a problem of moral hazard present, because detection is imperfect. Denote illegal logging by $X$ and let it be defined as 'excessive' harvesting, expressed by the difference between actual logging $Q$ and permitted logging $\bar{Q}$, i.e., $X \equiv(Q-\bar{Q})$. Given our interpretations above, excessive harvesting could be thought of as harvesting too much area, or as removal of too much volume. Timber trespass is a common form of the former, while high grading is a common form of the latter. With high grading, either too much volume is removed, or too much volume is removed from high valued species groups. We can consider the concession above in terms of species groups if we think of $\bar{Q}$ as a vector of species harvest allowances.

Let $p(\leq 1)$ denote the probability of illegal logging detected by the government. The government is not assumed to audit the harvester one hundred percent of the time, and so the frequency of auditing (i.e., the probability of detecting illegal logging) is a measure of the intensity with which the government monitors and detects illegal activities. We consider two types of penalties imposed by the government should cheating be detected. Both are common in government documents pertaining to concessions programs (Gray 2000) and have been analyzed in other literature on tax evasion (e.g. see Yitzhaki 1974 for penalties levied against evaded taxes and Allingham and Sandmo 1972 for penalties levied on undeclared incomes).

\footnotetext{
${ }^{3}$ In what follows, derivatives of a function with one argument is denoted with primes, while partial derivatives of functions with more than one argument are denoted by subscripts.
} 
The first penalty is a fine assessed against the concessionaire's undeclared gross harvest revenue from illegal logging not reported to the government. The concessionaire's actual profits in this penalty scheme would now depend on whether illegal logging is detected. If illegal logging is not detected with probability $(1-p)$, then actual profits are defined as,

$$
Y^{u}=\left[q Q^{u}-t q \bar{Q}-c\left(Q^{u}\right)+I\right]
$$

and if illegal logging is detected with probability $p$, then actual profits include the penalty,

$$
Z^{u}=\left\lfloor Y^{u}-f q X^{u}\right\rfloor
$$

where the ' $u$ ' superscript indicates the case where penalties are assessed on undeclared (evaded) gross harvest revenues, $f$ is the fine rate, $X^{u}$ is illegal harvesting under this penalty, and $I$ is the area-based royalty (fee or subsidy).

The second penalty system to consider is one where the penalty rate is levied on actual evaded royalty payments. Evaded royalty payments amount to fees the government would have collected if the concessionaire truthfully reported the harvest level to the government. Now the concessionaire's actual profit is written,

$$
Y=[q Q-t q \bar{Q}-c(Q)+I]
$$

if illegal logging is not detected with probability $(1-p)$, and

$$
Z=[Y-f t q X]
$$

if illegal logging is detected with probability $p$.

Given a positive probability of being caught, the precise incentive to illegally $\log$ depends on the harvester's risk preference. We allow for both risk neutrality and risk aversion. 


\subsection{Incentives for Illegal Logging: Risk Neutral Harvesters}

The risk-neutral harvester maximizes expected profits, defined under the two penalty schemes, respectively, as,

$\underset{Q^{u}}{\operatorname{Max}} E \pi=q Q^{u}-c\left(Q^{u}\right)-t q \bar{Q}+I-p q f X^{u}$, and

$\underset{Q}{\operatorname{Max}} E \pi=q Q-c(Q)-t q \bar{Q}+I-p t q f X$

First-order conditions for harvesting under each scheme are,

$$
\begin{aligned}
& Q^{u}: q-c^{\prime}\left(Q^{u}\right)-p q f=0, \text { and } \\
& Q: q-c^{\prime}(Q)-p q t f=0
\end{aligned}
$$

Both conditions show that optimal logging is defined by the equality of marginal revenue $(q)$ and expected marginal cost, which consists of harvest cost plus the expected fine payment $\left(c^{\prime}\left(Q^{u}\right)+p q f\right.$ or $\left.c^{\prime}(Q)+p q t f\right)$.

It is easy to show that illegal logging depends on exogenous parameters as follows.

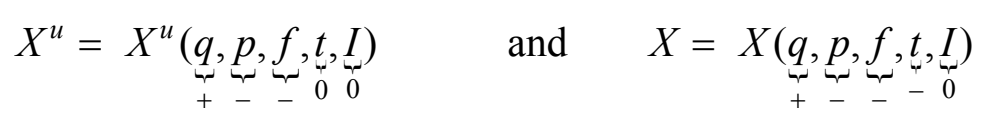

The effects of $q, f, p$ and $I$ on illegal logging are similar in both penalty cases. A higher timber price increases illegal logging, while a higher probability of detection and penalty reduce it. Changes in the area-based royalty $I$ will have no effect under risk neutrality. Interestingly, the effect of the $t$ on illegal logging depends on the penalty scheme. When the penalty is based on undeclared income, $t$ has no effect on actual logging and is a nondistortionary instrument. However, when the penalty is levied on evaded royalty payments, higher royalty rates decrease illegal logging; $t$ is now a distortionary instrument. This difference arises because increases in $t$ introduce a 
negative substitution effect on actual logging only with penalties levied on evaded royalty payments.

\subsection{Incentives for Illegal Logging: Risk-Averse Harvesters}

A risk-averse harvester's behavior will differ from that of a risk-neutral harvester. When the penalty is levied on undeclared income, the concessionaire maximizes the following expected utility function,

$$
\underset{Q^{u}}{\operatorname{Max}} E U(\pi)=(1-p) u\left(Y^{u}\right)+p u\left(Z^{u}\right),
$$

where $Y^{u}=\left[q Q^{u}-t q \bar{Q}-c\left(Q^{u}\right)+I\right]$ and $Z^{u}=\left\lfloor Y^{u}-f q X^{u}\right]$. The first-order condition for the optimal logging is,

$$
E U_{Q^{u}}=(1-p) u^{\prime}\left(Y^{u}\right) a+p u^{\prime}\left(Z^{u}\right) b=0
$$

where $a=q-c^{\prime}\left(Q^{u}\right)>0$ and $b=q-c^{\prime}\left(Q^{u}\right)-f q<0$. The second-order condition is,

$$
E U_{Q^{u}} u=(1-p) u^{\prime}\left(Y^{u}\right) a\left[-A\left(Y^{u}\right) a+A\left(Z^{u}\right) b\right]-c^{\prime \prime}\left(Q^{u}\right)\left((1-p) u^{\prime}\left(Y^{u}\right)+p u^{\prime}\left(Z^{u}\right)\right)<0
$$

where $A\left(Y^{u}\right)=-\frac{u^{\prime \prime}\left(Y^{u}\right)}{u^{\prime}\left(Y^{u}\right)}$ and $A\left(Z^{u}\right)=-\frac{u^{\prime \prime}\left(Z^{u}\right)}{u^{\prime}\left(Z^{u}\right)}$ denote the Arrow-Pratt measures of absolute risk-aversion (see Arrow 1974).

An interior solution requires that $E U_{Q^{u} \mid Q^{u}=\bar{Q}}>0 \Leftrightarrow q-\left[c^{\prime}\left(Q^{u}\right)+p f q\right]>0$. Thus for a risk-averse harvester to engage in illegal logging, the timber price must exceed the expected marginal cost of logging, which now includes the marginal cost of harvesting plus the expected fine payment. 
The comparative statics of harvesting and illegal logging for this case are reported in Appendix 1. We can express the effects of changes in exogenous variables as follows,

$$
\begin{aligned}
& X_{f}^{u}<0 \text { and } X_{p}^{u}<0 \\
& X_{I}^{u} \geq 0 \text { and } X_{t}^{u}=-q \bar{Q} X_{I}^{u} \leq 0
\end{aligned}
$$

A higher penalty rate and higher probability of detection both decrease illegal logging. Higher area-based royalty subsidies increase illegal logging under decreasing absolute risk aversion (DARA), but it has no effect under constant risk-aversion (CARA). This follows from the fact that greater rents for the harvester increase the incentive to capture rents illegally and risk a penalty, as long as risk aversion is decreasing in wealth. Naturally, for an area-based royalty fee, the sign is reversed under DARA, i.e. $X_{I}^{u}<0$. As for a higher value-based royalty rate, we find only an income effect but no substitution effect under DARA. Thus, harvesting and illegal logging are inversely related to the royalty rate $t$ under DARA.

Turning now to the penalty levied on evaded royalty payments, the concessionaire's expected utility maximization problem becomes,

$$
\underset{Q}{\operatorname{Max}} E U(\pi)=(1-p) u(Y)+p u(Z)
$$

where $Y$ and $Z$ are as defined earlier. The first- order condition is,

$$
E U_{Q}=(1-p) u^{\prime}(Y) \hat{a}+p u^{\prime}(Z) \hat{b}=0,
$$

where $\hat{a}=q-c^{\prime}(Q)>0$ and $\hat{b}=q-c^{\prime}(Q)-t f q<0$, and the second-order condition is,

$$
E U_{Q Q}=(1-p) u^{\prime}(Y) \hat{a}[-A(Y) \hat{a}+A(Z) \hat{b}]-c^{\prime \prime}(Q)\left[(1-p) u^{\prime}(Y)+p u^{\prime}(Z)\right]<0
$$

The first order condition (16) shows that the harvester's choice of logging equates expected marginal benefits from harvesting to expected marginal costs. An interior 
solution for illegal logging implies $E U_{Q \mid Q=\bar{Q}}>0 \Leftrightarrow q-\left[c^{\prime}(Q)+p t f q\right]>0$, with the interpretation being similar to the earlier case.

The comparative statics of illegal logging with respect to the fine, detection probability, and timber price parameters are qualitatively the same as when the penalty is assessed on undeclared income. There is again an important difference between penalty schemes concerning the effect of the value-based royalty $t$ on harvesting and illegal logging. When penalties are levied against evaded royalties, $t$ is a distortionary instrument. That is, in addition to having an income effect, it also induces a substitution effect on harvesting. In Appendix 2, we demonstrate that an increase in $t$ reduces illegal logging, i.e., $X_{t}<0$ under DARA, when the penalty is levied on undeclared income, and even under CARA when the penalty is levied on evaded royalty payments. We summarize our comparative statics results in the following,

Result 1. Illegal logging under risk-aversion and alternative penalty schemes. Illegal logging is inversely related to the fine rate and the probability of detection for both penalty schemes irrespective of risk aversion behavior. It is inversely related to the value-based royalty rate through an income effect under decreasing absolute risk aversion when the penalty is levied against undeclared income, but through income and substitution effects when the penalty is levied against evaded royalty payments, due to the substitution effect and the inverse relationship between illegal logging and royalty rates. The latter also holds under constant absolute risk aversion.

\section{Optimal design of royalties and auditing - Risk neutrality}

We now turn to our main objective, the socially optimal design of royalties and auditing. Because the socially optimal design of instruments presupposes a benevolent dictator interpretation for the policy maker, we conventionally assume that the government maximizes a net social welfare function, which includes the profits of the concessionaire and negative externalities caused by illegal logging. In practical terms, these externalities are associated with deforestation of expanding forest frontier boundaries, or with high grading of existing forest stocks, or both. We capture them by writing a function that depends on illegal logging, $v(X)$, with $v^{\prime}(X)<0$. The 
derivative of this function measures the negative externalities associated with deforestation through illegal logging. The social welfare function can now be written,

$$
S W=E \pi+v(X)
$$

The government must expend some type of auditing effort. The cost of auditing incurred by the government is an increasing and convex function of the probability of detection, $c(p)$, such that $c^{\prime}(p)>0, c^{\prime \prime}(p)>0$, and $c^{\prime}(0)=0 .{ }^{4}$ Finally, we assume that the government faces a constraint in terms of expected revenue collections. Expected government revenues depend on any royalty payments collected, fines collected, and the cost of auditing. When penalties for illegal logging are levied on undeclared income or evaded royalty payments, government revenues are specified respectively as,

$$
\begin{aligned}
& R^{u}=t q \bar{Q}+p f q X^{u}-c(p)-I, \text { and } \\
& R=t q \bar{Q}+p t f q X-c(p)-I
\end{aligned}
$$

\subsection{Penalty charged on undeclared income}

We first examine policy design under the assumption that negative externalities are not important or are ignored by the government. Under this payment scheme and risk neutrality, it turns out that the area-based royalty is equivalent to the value-based royalty, and so we restrict attention to only the value-based royalty $t$ in deriving results. We return to both area- and value-based royalties when the distinction matters.

From (18) the government would choose $t$ and the audit probability $p$ to maximize the expected indirect profit function $E \pi^{*}$ subject to $R^{u}=t q \bar{Q}+p f q X^{u}-I-c(p) \geq \bar{R}$. Writing the Lagrangian function for this problem as $\Omega^{u}=E \pi^{*}+\lambda\left(R^{u}-\bar{R}\right)$, and

\footnotetext{
${ }^{4}$ The high cost of auditing and enforcement of concessions activities has been cited as one reason why illegal logging is a problem in tropical countries with concessions. Because we define the cost of auditing as a function of the audit probability, it could in principle capture several features of this cost in practice, such as the inefficiency of the government in undertaking these actions.
} 
accounting for the harvester's response, we have the following necessary conditions for the choice of $t$ and $p$ :

$$
\begin{aligned}
& \Omega_{t}^{u}=-q \bar{Q}+\lambda q \bar{Q}=0, \text { and } \\
& \Omega_{p}^{u}=-f q X^{u}+\lambda\left[f q X^{u}+p f q Q_{p}^{u}-c^{\prime}(p)\right]=0 .
\end{aligned}
$$

The government chooses the royalty rate to equate marginal revenue collections, $\lambda q \bar{Q}$, to marginal costs, $q \bar{Q}$, defined in terms of the effects they have on welfare of the concessionaire. The multiplier of the government's revenue constraint is the marginal effect on social welfare of a change in the royalty rate, i.e. it is the marginal cost of public funds. ${ }^{5}$ From (21), we see that $\lambda=1$ at the optimal royalty choice - this means all required revenues should be collected using the value-based royalty instrument $t$, which is nondistortionary. Moreover, it is not optimal to allocate any of the government's resources to auditing activities, because expected marginal returns are smaller than the marginal cost of auditing. This can be seen by substituting $\lambda=1$ in $\Omega_{p}^{u}=0$, which gives $\left.\Omega_{p}^{u}\right|_{\lambda=1}<0$, implying $p=0$ at the optimum.

Our result explains an observation made in the literature. Some have argued that many developing country governments who employ royalties do not enforce illegal logging enough or at all (Johnson 2002). We have provided a benchmark case showing that this strategy may indeed be optimal for the policy maker, but under very specific conditions.

When the government responds to externalities the basic result above is modified. The social welfare function is now written as, $S W=E \pi^{*}+v\left(X^{u}\right)$, and $v^{\prime}\left(X^{u}\right)<0$ measures social costs associated with illegal logging. We now have the following first order conditions for the Lagrangian function: $\Omega^{u}=E \pi^{*}+v\left(X^{u}\right)+\lambda\left(R^{u}-\bar{R}\right)$,

\footnotetext{
${ }^{5}$ For a formal discussion of $\lambda$ and its implications for optimal tax instrument design in general, see Atkinson and Stiglitz (1980), or Myles (1995).
} 
$\Omega_{t}^{u}=-q \bar{Q}+\lambda q \bar{Q}=0$, and

$\Omega_{p}^{u}=-f q X^{u}+v^{\prime}\left(X^{u}\right) Q_{p}^{u}+\lambda\left\lfloor f q X^{u}+p f q Q_{p}^{u}-c^{\prime}(p)\right\rfloor=0$.

From (23) we continue to find that $\lambda=1$ at the optimal policy mix, so that required revenue should still be collected using the value-based royalty instrument. However, there is an additional welfare effect of auditing given by the second term in (24). This represents a reduction in the negative externality because of decreased illegal logging. It is now optimal for the government to allocate some royalty revenue collections to auditing activities. To see this, assume that the value-based royalty rate is set at its optimal level, $t=t^{*}$, and then use (23) to rewrite (24) as,

$$
\left.\Omega_{p}^{u}\right|_{t=t^{*}}=p f q Q_{p}^{u}-c^{\prime}(p)+v^{\prime}\left(X^{u}\right) Q_{p}^{u}
$$

Writing this condition at corner solutions of no auditing $p=0$ and perfect auditing $p=$ 1, we have $\left.\Omega_{p}^{u}\right|_{\substack{t=t^{*} \\ p=0}}=v^{\prime}\left(X^{u}\right) Q_{p}^{u}>0$, and $\Omega_{\substack{p \\ p=t^{*} \\ p=1}}=f q Q_{p}^{u}-c^{\prime}(1)+v^{\prime}\left(X^{u}\right) Q_{p}^{u}<0$, respectively. Comparing these suggests it is optimal to devote a share of the government's royalty revenues to auditing efforts.

In order to facilitate interpretation, we re-express (25) as follows,

$c^{\prime}(p)=\frac{p}{Q^{u}}\left(f q+\frac{1}{p} v^{\prime}\left(X^{u}\right)\right) \varepsilon_{p}^{u}$,

where $\varepsilon_{p}^{u}=\frac{Q_{p}^{u} p}{Q^{u}}<0$ and $p f q+v^{\prime}\left(X^{u}\right)<0$. Auditing is chosen so that the marginal cost of auditing (LHS) is equal to the marginal benefit (RHS). The marginal benefit includes the marginal expected fine revenue (first term) plus the marginal benefit of additional externalities that follow from reductions in illegal logging (second term). Hence, the amount of resources the government should devote to its auditing strategy depends on the difference between revenue collection changes and externality reductions that follow from policy-induced reductions in logging. 


\subsection{Penalty charged on evaded royalty payment}

Under this penalty scheme, the value-based royalty rate $t$ enters the harvester's penalty payment explicitly, and there is an important distinction between it and the area-based royalty, so we explicitly examine both instruments. Assuming first that the government omits or ignores negative externalities from deforestation, we have the following maximization $\quad$ problem: $S W=E \pi^{*}$ subject to $R=t q \bar{Q}+p t f q X-I-c(p) \geq \bar{R}$. The choice of area-based royalty fee is given by $\Omega_{I}=-1+\lambda=0$, and the necessary conditions for the Lagrangian, $\Omega=E \pi^{*}+\lambda(R-\bar{R})$, in terms of the government's choices of $t$ and $p$ are:

$\Omega_{t}=-(q \bar{Q}+p q f X)+\lambda\left[q \bar{Q}+p q f X+p q f t Q_{t}\right]=0$, and

$\left.\Omega_{p}=-f q t X+\lambda \mid f q t X+p f q t Q_{p}-c^{\prime}(p)\right\rfloor=0$

$\lambda=1$ implies that the government should use only the area-based royalty fee and set $t$ $=0$. This is because the value-based royalty $t$ is a distortionary instrument and induces a negative substitution effect on logging, while $I$ is a lump sum instrument here. Moreover, it is not optimal to allocate any of the government's resources to auditing activities, because expected marginal returns are smaller than the marginal cost of auditing. This can be seen by substituting $\lambda=1$ in $\Omega_{p}^{u}=0$, which gives $\left.\Omega_{p}^{u}\right|_{\lambda=1}<0$, implying $p=0$ at the optimum.

When the government accounts for negative externalities arising from deforestation, the optimal policy design is now different. The choice of area-based royalty fee is given by $\Omega_{I}=-1+\lambda=0$, and the choice of the optimal value-based royalty and the auditing probability are now defined by,

$$
\begin{aligned}
& \Omega_{t}=-(q \bar{Q}+p q f X)+v^{\prime}(X) Q_{t}+\lambda\left[q \bar{Q}+p q f X+p q f t Q_{t}\right]=0, \text { and } \\
& \left.\Omega_{p}=-f q t X+v^{\prime}(X) Q_{p}+\lambda \mid f q t X+p f q t Q_{p}-c^{\prime}(p)\right]=0 .
\end{aligned}
$$


Under $\lambda=1(29)$ and (30) can be written as

$$
\begin{aligned}
& \Omega_{t}=0 \Leftrightarrow v^{\prime}(X)+p q f t=0, \text { and } \\
& \Omega_{p}=v^{\prime}(X) Q_{p}+p f q t Q_{p}-c^{\prime}(p)=0 .
\end{aligned}
$$

According to (29') it is optimal to introduce a positive value-based royalty along with an area-based royalty fee. Proceeding as before, we can evaluate (30') assuming $t=t^{*}$ at the corner solutions for auditing probabilities to obtain, $\left.\Omega_{p}\right|_{\substack{t=t^{*} \\ p=0}}=v^{\prime}(X) Q_{p}>0$, and $\left.\Omega_{p}\right|_{\substack{t=t^{*} \\ p=1}}=-c^{\prime}(1)<0$, where we have used (29') with $p=1$. These conditions indicate that it is also optimal to devote resources to auditing as long as externalities arise from deforestation. We can collect our policy design findings in,

\section{Result 2. Policy design under risk neutrality.}

When the penalty is assessed on undeclared income, revenue should always be collected with a positive value-based royalty rate, which is non-distortionary. When the penalty is assessed on evaded royalty payments, revenues should be collected using an area-based royalty fee in the absence of negative externalities, and using a combination of area-based and value-based royalties in the presence of externalities. Auditing is optimal to enforce illegal logging under both penalty schemes when externalities are present.

\section{$4 \quad$ Optimal design of royalties and auditing - Risk aversion}

Because risk aversion is sensitive to income changes, it now makes sense to examine its implication to optimal design or royalty and auditing instruments. Therefore, we allow for the possibility that the royalty system is progressive or regressive, in the sense that the royalty system includes an area-based royalty subsidy or fee. In the taxation literature, progressivity (regressivity) means that the average tax rate is increasing (decreasing) in the tax base, i.e., in the value of the concession (Musgrave and Thin 1948).

In the presence of progression, the concessionaire's revenues are defined as $Y=[q Q-(t q \bar{Q}-I)-c(Q)]$ and $Z=[Y-f q X]$ when a penalty is assessed against 
evaded royalty payments, and $Y^{u}=\left[q Q^{u}-(t q \bar{Q}-I)-c\left(Q^{u}\right)\right]$ and $Z^{u}=\left[Y^{u}-f q X\right]$ when the penalty is assessed against unreported income. Using these definitions, expected government royalty collections become $R=(t q \bar{Q}-I)+p t f q X-c(p)$ and $R^{u}=(t q \bar{Q}-I)+p f q X^{u}-c(p)$ respectively under the two penalty schemes.

Finally, with risk aversion the social welfare function is now given by expected indirect utility of the harvester plus externalities foregone by protecting forests, i.e. $S W=E U(\pi)^{*}+v(X)$.

\subsection{Penalty charged on undeclared income}

The government now chooses value-based and area-based royalty rates, and the audit probability to solve the following problem,

$$
\underset{t, I, p}{\operatorname{Max}} S W=E U(\pi)^{*}+v\left(X^{u}\right) \text { s.t. } R^{u}=(t q \bar{Q}-I)+p f q X^{u}-c(p) \geq \bar{R} .
$$

Like in the previous section, we first study the case where either there is no externality associated with deforestation or the government ignores it, and then we consider the case where externalities are important.

\section{A. Externalities ignored}

With the externality term $v\left(X^{u}\right)$ set equal to zero, the first order conditions for the problem in (31) for the value-based royalty rate, area-based royalty, and auditing are written,

$$
\begin{aligned}
& \Omega_{t}^{u}=-\left[(1-p) u^{\prime}\left(Y^{u}\right)+p u^{\prime}\left(Z^{u}\right)\right] q \bar{Q}+\lambda\left[q \bar{Q}+p f q Q_{t}^{u}\right]=0, \\
& \left.\Omega_{I}^{u}=\left[(1-p) u^{\prime}\left(Y^{u}\right)+p u^{\prime}\left(Z^{u}\right)\right]-\lambda \mid 1-p f q Q_{I}^{u}\right]=0, \text { and } \\
& \Omega_{p}^{u}=-\left[u\left(Y^{u}\right)+u\left(Z^{u}\right)\right]+\lambda\left[f q X^{u}+p f q Q_{p}^{u}-c^{\prime}(p)\right]=0 .
\end{aligned}
$$


According to (32) the government chooses the royalty $t$ to equate marginal revenue collections (RHS) with the marginal effect of the royalty on welfare, measured in expected utility terms (LHS). Using the fact that $Q_{t}^{u}=-q \bar{Q} Q_{I}^{u}$ from (32) and (33), we can re-express the optimality condition for $I$ in a form identical to the optimal valuebased royalty condition. Doing so shows that use of $I$ is not needed when $t$ is set at its optimal level - progression is not optimal. We show later that this result changes when the penalty is charged on evaded royalty payments.

We can express the optimal value-based royalty rate in closed form, and investigate how it depends on parameters of the problem. From the first-order conditions we have,

$\Omega_{t}^{u}=0 \Leftrightarrow p u^{\prime}\left(Z^{u}\right) \frac{f q}{q-c^{\prime}\left(Q^{u}\right)}=\lambda\left[1+\frac{p f Q^{u}}{\bar{Q}} \varepsilon_{t}\right]$, where $\varepsilon_{t}=\frac{Q_{t}^{u} t}{Q^{u}} \leq 0$ as $A^{\prime} \leq 0$. Solving for $Z^{u}$ gives $Z^{u}=u^{\prime-1}(\Delta)$, with $\Delta=\left(1+\frac{p f Q^{u}}{\bar{Q}} \varepsilon_{t}\right)$. Using next the definition of $Z^{u}$ we have the following optimal royalty rate expression:

$t^{*}=\frac{q Q^{u}-c\left(Q^{u}\right)-f q X^{u}}{q \bar{Q}}-\frac{u^{\prime-1}(\Delta)}{q \bar{Q}}$.

Notice first that the derivative of the optimal royalty rate with respect to $\Delta$ is $t_{\Delta}^{*}=-\frac{u^{\prime \prime-1}(\Delta)}{q \bar{Q}}>0$. Thus, we can examine how the size of the optimal royalty rate depends on the other parameters of the model. $t^{*}$ has the following properties: $t_{\varepsilon_{t}}^{*}<0$, $t_{p}^{*}<0$, and $t_{f}^{*}<0$.

There are three interpretations that follow from (35). First, the optimal valuebased rate decreases as the elasticity of harvesting with respect to the royalty rate increases. When harvests are very elastic in terms the royalty rate, this means that large royalty rates will reduce welfare more and increase the inability of the government to collect revenues as harvesting declines. The opposite is true if harvesting elasticity is low. Second, the audit probability and the penalty rate are substitute instruments for the royalty. If the probability of detection is low, as it is in most developing countries, then 
higher royalty rates are needed for the government to satisfy its revenue constraint, ceteris paribus; this is because illegal logging, which reduces revenues the government captures, increases as the detection probability decreases. Third, the optimal royalty rate is lower when the fine imposed for illegal logging is higher. These three results collectively show that the design of royalty instruments and of auditing and fines cannot be considered separately, as they are often discussed in the literature on concessions and illegal logging.

We can also show how resources should be allocated for detection of illegal logging. From (34) we develop the following modified condition,

$$
c^{\prime}(p)=\frac{u\left(Z^{u}\right)-u\left(Y^{u}\right)}{\lambda}+f q X^{u}\left(1+\frac{Q^{u}}{X^{u}} \varepsilon_{p}\right)
$$

From (36), it is always optimal for the government to devote resources to auditing. The allocation of resources to detection activities depends on the direct effect on the expected utility of these efforts, and on the sum of the immediate and indirect effects of higher detection rate on illegal logging as well as on the marginal cost of public funds. We summarize our findings in,

\section{Proposition 1. Optimal royalty and auditing design under risk aversion when penalty is levied on undeclared income.}

When externalities are not present, the optimal value-based royalty is positive. Introducing an area-based royalty fee or subsidy is not optimal when the valuebased royalty is set to its optimal level. The optimal value-based royalty rate is inversely related to the elasticity of harvesting with respect to the royalty rate, the audit probability, and the fine rate. Auditing of illegal logging is always optimal.

\section{B. Externalities included}

When externalities are present and the government responds to them, the firstorder conditions for the government's choice of instruments become,

$$
\begin{aligned}
& \Omega_{t}^{u}=-\left[(1-p) u^{\prime}\left(Y^{u}\right)+p u^{\prime}\left(Z^{u}\right)\right] q \bar{Q}+v^{\prime}\left(X^{u}\right) Q_{t}^{u}+\lambda\left[q \bar{Q}+p f q Q_{t}^{u}\right]=0, \\
& \Omega_{I}^{u}=\left\lfloor(1-p) u^{\prime}\left(Y^{u}\right)+p u^{\prime}\left(Z^{u}\right)\right]+v^{\prime}\left(X^{u}\right) Q_{I}^{u}-\lambda\left[1-p f q Q_{I}^{u}\right\rfloor=0, \text { and }
\end{aligned}
$$


$\Omega_{p}^{u}=-\left[u^{\prime}\left(Y^{u}\right)-u\left(Z^{u}\right)\right]+v^{\prime}\left(X^{u}\right) Q_{p}^{u}+\lambda\left[f q X^{u}+p f q Q_{p}^{u}-c^{\prime}(p)\right]=0$,

As is evident from (37) and (38), our earlier results remain valid. That is, it is never optimal for the government to employ the area-based royalty given it uses the optimal value-based royalty $t$, as long as the penalty is levied on undeclared income. For the optimal auditing policy, we can after some rearranging arrive at the following condition,

$c^{\prime}(p)=\frac{u\left(Z^{u}\right)-u\left(Y^{u}\right)}{\lambda}+\frac{v^{\prime}\left(X^{u}\right)}{\lambda} \frac{q}{Q^{u}} \varepsilon_{p}+f q X^{u}\left(1+\frac{Q^{u}}{X^{u}} \varepsilon_{p}\right)$

The LHS is the marginal cost of auditing for a given probability of detection. The RHS measures the welfare cost of the policy on harvesters (first term), the welfare benefit of reductions in deforestation (second term), and marginal revenue collection by the government (third term). Notice that, relative to the case where negative externalities were absent, the RHS of this condition is larger. Thus, given the convex auditing cost function, it is optimal for the society to devote more resources to auditing activities in this case, as the marginal benefits of reductions in illegal logging are greater. This implies, naturally, that under DARA the value-based royalty rate will also be higher than in the previous case.

Corollary 1. Importance of externalities for policy design under risk aversion when penalty is levied on undeclared income

When negative externalities arise from illegal logging, then given the optimal value-based royalty rate, introducing an area-based royalty fee or subsidy is not optimal. The optimal value-based royalty rate is higher under decreasing absolute risk aversion and auditing is higher when externalities are present.

\subsection{Penalty charged on evaded royalty payment}

When the penalty is charged against evaded royalty payments, the concessionaire's revenues for the alterative outcomes under non-detection and detection of illegal logging are, $Y=[q Q-(t q \bar{Q}-I)-c(Q)]$ and $Z=[Y-t f q X]$, respectively. The 
government's revenue constraint is also modified accordingly, and the policy choice problem becomes,

$\underset{t, I, p}{\operatorname{Max}} S W=E U(\pi)^{*}+v(X) \quad$ s.t. $R=(t q \bar{Q}-I)+p t f q X-c(p) \geq \bar{R}$

\section{A. Externalities ignored}

Neglecting for the moment the externality term, the first order conditions are,

$$
\begin{aligned}
& \Omega_{t}=-\left[(1-p) u^{\prime}(Y) q \bar{Q}+p u^{\prime}(Z)(q \bar{Q}+q f X)\right]+\lambda\left[(q \bar{Q}+p q f X)+p f q t Q_{t}\right]=0, \\
& \Omega_{I}=\left[(1-p) u^{\prime}(Y)+p u^{\prime}(Z)\right]+\lambda\left[-1+p f q t Q_{I}\right]=0, \text { and } \\
& \Omega_{p}=-[u(Y)-u(Z)]+\lambda\left\lfloor t f q X+p f q t Q_{p}-c^{\prime}(p)\right]=0,
\end{aligned}
$$

where (43) describes the optimal area-based royalty. Using the condition $\Omega_{I}=0$, we have $\lambda=\frac{(1-p) u^{\prime}(Y)+p u^{\prime}(Z)}{1-p f q t Q_{I}} \geq 1$, so that $\lambda \geq(1-p) u^{\prime}(Y)+p u^{\prime}(Z)$ as $Q_{I} \geq 0$. Given $I=I^{*}$ the first-order condition (42) can be re-expressed after some rearranging as,

$t^{*}: \quad \frac{u^{\prime}(Z)-\lambda}{\lambda}=\frac{t}{X}\left[q \bar{Q} Q_{I}+Q_{t}\right]$

where $\left[q \bar{Q} Q_{I}+Q_{t}\right]=Q_{t}^{c}-x q \bar{Q} Q_{I}<0$ with $x=\frac{f X}{\bar{Q}}>0($ see Appendix 2$)$. Since the LHS and bracketed RHS term of (42') are negative, the optimal value-based royalty rate $t^{*}$ must be positive. According to (43), the optimal area-based royalty subsidy should be chosen in a manner that equates marginal welfare gain to the concessionaire, $(1-p) u^{\prime}(Y)+p u^{\prime}(Z)$, to marginal cost of public funds due to royalty revenue collections, $\lambda\left[1-p f q t Q_{I}\right]$. If the government employs an area-based royalty fee, instead of a subsidy, then we can rewrite (43) simply as: $\Omega_{I}=-\left[(1-p) u^{\prime}(Y)+p u^{\prime}(Z)\right]+\lambda\left[1+p f q t Q_{I}\right]=0$, where $Q_{I} \leq 0$ as $A^{\prime}() \leq$.0 . In this 
case the Slutsky equation for the value-based royalty rate $t$ is $Q_{t}=Q_{t}^{c}+q \bar{Q}(1-x) Q_{I}$. Given $I=I^{*}$ the first-order condition (42) can now be re-expressed to obtain,

$t^{*}: \quad \frac{u^{\prime}(Z)-\lambda}{\lambda}=\frac{t}{X}\left[-q \bar{Q} Q_{I}+Q_{t}\right]$

where $-\left[q \bar{Q} Q_{I}+Q_{t}\right]=Q_{t}^{c}+x q \bar{Q} Q_{I}<0$. Hence, the optimal value-based royalty rate $t^{*}$ is again positive, so that when penalties are charged against evaded royalty payments, both area-based and value-based royalty instruments should be used - this is similar to the policy mix we found to be optimal under risk neutrality.

These results raise the following question: should the government use an areabased royalty subsidy or fee as a supplement to the value-based royalty? The answer depends on the size of the tax revenue requirement the government seeks to collect. If the value-based royalty applied together with the auditing strategy is not sufficient to meet the revenue requirement, then the government should use an area-based royalty fee, but not the subsidy, when using a value-based royalty. This case is counter to the typical practice of using both a value-based royalty and an area-based subsidy by governments with concessions in tropical countries. In the case we have established, this means the optimal royalty structure is regressive.

Finally we turn to the government's auditing strategy. From the corresponding condition for $\Omega_{p}=0$ in (44), we can establish that it is always optimal to devote resources to auditing for illegal logging. The allocation of resources is defined by the following condition,

$$
c^{\prime}(p)=\frac{u(Z)-u(Y)}{\lambda}+f q X\left(1+\frac{Q}{X} \varepsilon_{p}\right)
$$

Thus, the allocation of auditing resources depends on its negative direct effect on the expected utility of the concessionaire, as well as the positive sum of immediate and indirect effects of higher detection rates on illegal logging and, thus, government revenue collections. The following proposition summarizes the above results, 


\section{Proposition 2. Optimal royalty and auditing design under risk aversion when penalty is levied on evaded royalty payments}

When externalities are not present, the optimal value-based royalty rate is positive. It is optimal to introduce an area-based royalty, and the royalty system may be progressive or regressive. The higher the government tax revenue requirement, the more likely the system should be regressive. Auditing of illegal logging is always optimal.

\section{B. Externalities included}

Finally, we consider briefly how externalities modify policy choices under this penalty scheme. Consider the first-order conditions governing the choice of instruments,

$$
\begin{aligned}
& \Omega_{t}=-\left[(1-p) u^{\prime}(Y) q \bar{Q}+p u^{\prime}(Z)(q \bar{Q}+q f X)\right]+v^{\prime}(X) Q_{t}+\lambda\left[(q \bar{Q}+p q f X)+p f q t Q_{t}\right]=0 \\
& \Omega_{I}=\left[(1-p) u^{\prime}(Y)+p u^{\prime}(Z)\right]+v^{\prime}(X) Q_{I}-\lambda\left[1-p f q t Q_{I}\right]=0, \text { and } \\
& \left.\Omega_{p}=-[u(Y)-u(Z)]+v^{\prime}(X) Q_{p}+\lambda \mid f q t X+p f q t Q_{p}-c^{\prime}(p)\right]=0 .
\end{aligned}
$$

As is evident from the conditions $\Omega_{t}=0$ and $\Omega_{I}=0$, our previous results continue to hold if the expected revenue loss from a higher value-based royalty rate $\left(\lambda p q f Q_{t}\right)$ is greater than the positive welfare effect due to resulting lower illegal logging $\left(v^{\prime}(X) Q_{t}\right)$. Looking at the second RHS terms in (47-49) we can see that under this condition the value-based royalty rate is higher and the area-based royalty subsidy is lower than in the absence of externalities. This implies that allowing for externalities will increase the likelihood of a regressive royalty system being optimal, because higher royalty rates decrease illegal logging.

For the optimal probability of detection we have,

$c^{\prime}(p)=\frac{u(Z)-u(Y)}{\lambda}+\frac{v^{\prime}(X)}{\lambda} \frac{q}{Q} \varepsilon_{p}+f q X\left(1+\frac{Q}{X} \varepsilon_{p}\right)$

Thus, the RHS of (50) is higher than the RHS of (46), and so the government should devote more resources to auditing when externalities are present given that enforcement 
costs are convex. This finding clearly indicates that it is optimal for the society to devote more resources to auditing activities in order to prevent illegal logging and deforestation. We summarize these findings as,

Corollary 2. Importance of externalities to policy design under risk aversion when penalty is levied on evaded royalty payments.

When negative externalities arise from illegal logging, the optimal value-based royalty rate is positive and auditing effort continues to be optimal, but more resources should be devoted to auditing compared to the case where externalities are absent. The optimal area-based royalty subsidy is lower, or equivalently the optimal area-based royalty fee is higher.

\section{Conclusions}

We address the socially optimal design of instruments in economies with concessions, arriving at several benchmark results. We consider both area-based and value-based royalty instruments, as well as auditing choices, in a context where illegal logging can occur. We also examine the common case where combinations of royalty fees and subsidies are used, that is, we examine the optimality of progressivity or regressivity in the instrument system. Two Important distinctions we also consider in the choice of instruments are how the penalty scheme is structured for punishment of illegal logging, and whether externalities are present that are reduced by illegal logging.

The form of illegal logging we consider is the most common, i.e., one in which the concessionaire harvests more than is contracted for in the concession. Illegal logging activity is not detectable by the government unless costly auditing is employed. Auditing ensures that detection occurs with some positive probability. Should the government detect illegal logging, two possible penalty schemes are modeled: a fine assessed on undeclared harvest income, and a fine assessed on evaded royalty payments. Increasing auditing probabilities is consistent with use of greater government resources to detect illegal logging.

Within this framework we evaluate two questions: First, how do incentives for harvesters to illegally log depend on government auditing effort and royalty choices,

and second, how should a benevolent policy maker employ instruments to achieve the social optimum while facing revenue constraints on their choices. When forest 
harvesters are risk neutral, policy choices depend on the presence of externalities (or the government's preference to provide them) and on the penalty scheme.

When the penalty is assessed on undeclared income, the value-based or areabased royalties are equivalent, so that a positive value-based optimal royalty implies the area-based royalty is not needed. But the government will never find it optimal to completely eliminate illegal logging even when forest externalities are lost through such activities. When negative externalities are not present, auditing will not be employed. When penalties are imposed on evaded royalty payments, both the valuebased and area-based royalties should be used, and auditing is optimal only if negative externalities are present.

The case where harvesters are risk averse leads to different instrument choice results, some of which are in striking contrast with the way royalty systems are currently employed or discussed. In the absence of externalities and when penalties are assessed on undeclared income, neither an area-based royalty fee or an area-based royalty subsidy are optimal, but a value-based royalty is optimal and should be inversely related to the elasticity of harvesting with respect to the royalty rate, the audit probability, and the fine rate. Auditing of illegal logging is also optimal. When externalities are absent and penalties are levied on evaded royalty payments, we find the counterintuitive result that a royalty system may be either progressive or regressive, so that there is scope for an area-based fee or subsidy; the correct instrument mix depends on the importance of the government's revenue constraint. When externalities are present, the value-based royalty rate should be higher, progression lower, and regression higher. More resources should also be devoted to auditing compared to the case where externalities are absent.

These contrasting results suggest that royalties and enforcement of illegal logging must be balanced in ways that have not even been discussed in the literature, let alone applied in countries with concessions. The benchmark cases here suggest that area-based and value-based royalties have important differences in some cases, and important similarities in others. In all cases, the design of these policies is quite complicated and depends on the risk preferences of harvesters, the way enforcement and fines are structured, and how governments view externalities associated with illegal logging. Whether a combination of instruments is needed, or whether the instruments 
should be progressive or regressive, all depend critically on specific characteristics of each application. For example, we establish cases where a government would not choose to audit for illegal logging at all, i.e., when harvesters are risk neutral and the government does not respond to externalities associated with deforestation or illegal logging. 


\section{Appendix 1. Comparative Statics of Instruments under Risk-Aversion}

Penalty fine rate, and detection probability:

$$
\begin{gathered}
Q_{f}^{u}=-\frac{E U}{E U Q_{f} u_{Q^{u}}}<0, \text { where } E U_{Q^{u} f}=-\left[q X^{u} u^{\prime \prime}\left(Z^{u}\right) b+q u^{\prime}\left(Z^{u}\right)\right]<0 \\
Q_{p}^{u}=-\frac{E U}{E U Q_{p}}<0, \text { where } E U_{Q^{u} p}=-u^{\prime}\left(Y^{u}\right) a+u^{\prime}\left(Z^{u}\right) b<0 .
\end{gathered}
$$

Exogenous income and royalty rate:

$Q_{I}^{u}=-\frac{E U}{E U{ }_{Q} u_{I}} \leq 0$, when $A^{\prime}() \leq 0$,

where $E U_{Q^{u} I}=-a(1-p) u^{\prime}\left(Y^{u}\right)\left[A\left(Y^{u}\right)-A\left(Z^{u}\right)\right] \geq 0$, and

$Q_{t}^{u}=-\frac{E U_{Q^{u} t}}{E U_{Q^{u} Q^{u}}} \leq 0$, when $A^{\prime}() \leq 0$,

where $E U_{Q_{t}^{u}}=q \bar{Q} a(1-p) u^{\prime}\left(Y^{u}\right)\left[A\left(Y^{u}\right)-A\left(Z^{u}\right)\right] \leq 0$. A1.4 can be decomposed into the income and substitution effects (see Appendix 2)

$$
Q_{t}^{u}=Q_{t}^{c}-q \bar{Q} Q_{I}^{u}, \quad \text { where } \quad Q_{t}^{c}=Q_{t}^{u}+g \bar{Q} Q_{I}^{u}=0
$$

so that the substitution effect of the royalty rate is zero.

\section{Appendix 2. Slutsky Decompositions for the Royalty Rate}

We develop Slutsky decompositions for the total effect of the royalty rate $t$ on logging under the alternative penalty schemes.

\section{A. Penalty on undeclared income}

The concessionaire's expected utility is,

$$
E U(\pi)=(1-p) u\left(Y^{u}\right)+p u\left(Z^{u}\right)
$$

where $Y^{u}=q Q^{u}-c\left(Q^{u}\right)-t q \bar{Q}+I, Z^{u}=Y^{u}-f q\left(Q^{u}-\bar{Q}\right)$ and $I$ is the area-based royalty. The first-order condition for the optimal logging $E U_{Q}{ }^{u}=0$ implicitly defines $Q^{u}$ as $Q^{u} \equiv Q^{u}(t, I)$. Substituting $Q^{u}(t, I)$ for $Q$ in A.2.1 gives expected indirect utility $E U^{*}(t, I)=U^{o}$, with the following properties holding due to the envelope theorem, 


$$
\begin{array}{lr}
E U_{I}^{*}=(1-p) u^{\prime}\left(Y^{u}\right)+p u^{\prime}\left(Z^{u}\right)>0, \text { and } & \text { A2.2a } \\
E U_{t}^{*}=-q \bar{Q} E U_{I}^{*}<0 . & \mathrm{A} 2.2 \mathrm{~b}
\end{array}
$$

Inverting $E U^{*}$ for $I$ to obtain $I=h\left(t, U^{o}\right)$ and substituting this for $I$ in $E U^{*}$ we obtain the compensated expected indirect utility function (see Diamond-Yaari (1972))

$$
E U^{*}\left(t, h\left(t, U^{o}\right)\right)=U^{o}
$$

Differentiating A2.3 with respect to the royalty tax rate yields: $E U_{t}^{*}+E U_{I}^{*} h_{I}=0$, and holding the expected utility constant gives,

$$
h_{I}=-\frac{E U_{t}^{*}}{E U_{I}^{*}}=q \bar{Q}>0
$$

From the duality theorem (see e.g. Varian 1992, pp. 81-93), the relationship between uncompensated logging, $Q^{u}$, and compensated logging, $Q^{c}$, is,

$$
Q^{u}\left(t, h\left(t, U^{o}\right)\right)=Q^{c}\left(t, U^{o}\right)
$$

Differentiating A2.5 with respect to the royalty rate yields $Q_{t}+Q_{I} h_{t}=Q_{t}^{c}$, and using A2.4 we obtain,

$$
Q_{t}^{u}=Q_{t}^{c}-q \bar{Q} Q_{I}^{u}
$$

where the total effect is decomposed into the substitution effect $\left(Q_{t}^{c}\right)$ and the income effect $\left(-q \bar{Q} Q_{I}^{u}\right)$.

The total effect of the royalty rate is given by the expression,

$$
Q_{t}^{u}=-\frac{E U_{Q^{u} t}}{E U_{Q^{u} Q^{u}}} 0, \text { where } E U_{Q^{u} t}=q \bar{Q}\left(q-c^{\prime}\left(Q^{u}\right)\right)(1-p) u^{\prime}\left(Y^{u}\right)\left[A\left(Y^{u}\right)-A\left(Z^{u}\right)\right\rfloor
$$

The effect of non-logging income can be expressed similarly as,

$$
Q_{I}^{u}=-\frac{E U_{Q^{u} I}}{E U_{Q^{u} Q^{u}}}, \text { where } E U_{Q^{u} I}=-\left(q-c^{\prime}\left(Q^{u}\right)\right)(1-p) u^{\prime}\left(Y^{u}\right)\left[A\left(Y^{u}\right)-A\left(Z^{u}\right)\right]
$$

Thus in the case of the penalty assessed on undeclared income we have, $Q_{t}^{c}=Q_{t}^{u}+q \bar{Q} Q_{I}^{u}=0$.

\section{B. Penalty on evaded royalty payment}


When the penalty is assessed on evaded royalty payments, the concessionaire's expected utility income terms in A.1 are written $Y=q Q-c(Q)-t q \bar{Q}+I$ and, so that first order conditions become,

$$
\begin{aligned}
& E U_{I}^{*}=(1-p) u^{\prime}(Y)+p u^{\prime}(Z)>0 \\
& E U_{t}^{*}=-q \bar{Q}(1+x) E U_{I}^{*}>0
\end{aligned}
$$

where $x=\frac{f X}{\bar{Q}}>0$. We can use A2.8a to invert the expected indirect utility function and obtain the corresponding compensated utility function

$$
h_{I}=-\frac{E U_{t}^{*}}{E U_{I}^{*}}=q \bar{Q}(1+x)>0
$$

Using the relationship between uncompensated and compensated logging behavior, like in A2.5, and equation A2.9, we can derive the following Slutsky equation for the effect of the royalty rate on logging,

$$
Q_{t}=Q_{t}^{c}-q \bar{Q}(1+x) Q_{I}
$$

We know that the total effect of the royalty rate is given by,

$$
Q_{t}=-\frac{E U_{Q t}}{E U_{Q Q}}<0
$$

where $E U_{Q t}=q \bar{Q}(1+x)\left(q-c^{\prime}(Q)(1-p) u^{\prime}(Y)[A(Y)-A(Z)]-p u^{\prime}(Z) f q<0\right.$ under nonincreasing absolute risk aversion. Moreover, we have previously shown,

$$
Q_{I}=-\frac{E U_{Q I}}{E U_{Q Q}} \text { where } E U_{Q I}=-\left(q-c^{\prime}(Q)\right)(1-p) u^{\prime}(Y)[A(Y)-A(Z)] \geq 0 \text { as } A^{\prime}(.) \leq 0
$$

Using A2.11 and A2.12 yields negative substitution effects,

$$
Q_{t}^{c}=Q_{t}+q \bar{Q}(1+x) Q_{I}=\left(-E U_{Q Q}\right)^{-1}\left\{-f q p u^{\prime}(Z)\right\}<0,
$$

In the case of $I<0$, the following Slutsky equations are obtained,

$$
Q_{t}=Q_{t}^{c}+q \bar{Q}(1+x) Q_{I}
$$

where $Q_{t}<0$ and $Q_{I} \leq 0 \quad$ as $A^{\prime}() \leq$.0 . Now we end up with $Q_{t}^{c}=Q_{t}-q \bar{Q}(1+x) Q_{I}=\left(-E U_{Q Q}\right)^{-1}\left\{-\right.$ fqpu $\left.^{\prime}(Z)\right\}<0$. 


\section{Literature Cited}

Allingham, M.G. and A. Sandmo. 1972. Income Tax Evasion: A Theoretical Analysis, Journal of Public Economics 1, 323-338.

Amacher, G. and R. Brazee. 1997. Designing Forest Taxes with Budget Targets and Varying Government Preferences, Journal of Environmental Economics and Management 32, 323-340.

Amacher, G., R. Brazee and M. Witvliet 2001. Royal Systems, Government Revenues, and Forest Conditions: An Application from Malaysia. Land Economics 77, 300-313.

Amacher, G. 1999. "Government Preferences and Public Forest Harvesting: A Second Best Approach.” American Journal of Agricultural Economics 81(1):14-28.

Arrow, K.J. 1974. Essays in the Theory of Risk-Bearing, North Holland, Amsterdam.

Atkinson, A.B. and J.E. Stiglitz. 1980. Lectures on Public Economics, McGraw-Hill, New York.

Clarke, H., W. Reed, and R. Shrestha 1993. Optimal Enforcement of Property Rights on Developing Country Forests Subject to Illegal Logging. Resource and Energy Economics 15, 271-93.

Cowell, F.A. 1987. The Economic Analysis of Tax Evasion, in Hey, J.D. and P.J. Lambert (eds): Surveys in the Economics of Uncertainty, Basil Blackwell, Oxford, pp. 173-203.

Deacon, R. 1992. Controlling Tropical Deforestation: An Analysis of Alternative Policies.University of California at Santa Barbara, Department of Economics Working Paper: 4-92 January 1992.

Diamond, P. and M. Yaari 1972. Implications of the Theory of Rationing for Consumer Choice under Uncertainty. American Economic Review 62, 333-343.

Gray, J. 2000. Forest Concession Policies and Revenue Systems: Country Experience and Policy Changes for Sustainable Tropical Forestry. World Bank Technical Paper, Forest Series, Washington D.C.

ITTO. 2002. Forest Crime: the midst clears. Tropical forest Update 12(1).

Johnson, S. 2002. Documenting the undocumented. Tropical Forest Update 12(1):6-14

Koskela, E. and M. Ollikainen. 1997. Optimal Design of Forest Taxation with MultipleUse Characteristics of Forest Stands, Environmental and Resource Economics 3:2, 107-132.

Milliman, S. 1986. Optimal Fishery Management in the Presence of Illegal Activity. Journal of Environmental Economics and Management, 13, 363-381.

Ministry of the Environment, Ministério do Meio Ambiente (MMA). 2001. National Forest Program PNF. Brasília, Brazil. 52 pp.

Musgrave, R.A. and T. Thin. 1948. Income Tax Progression, 1929-1948, Journal of Political Economy 56, 498-511.

Myles, G.D. 1995. Public Economics, Cambridge University Press.

Polinsky, A.M. and S. Shavell. 1979. The Optimal Tradeoff between the Probability and Magnitude of Fines, American Economic Review 68(5), 880-891.

Palmer, C. 2000 The Extent and Causes of Illegal Logging: An Analysis of a Major Cause of Deforestation in Indonesia. CSERGE Working Paper 0967.

Poore, E. 1993. The Sustainable Management of Tropical Forests: the Issues, in The Earthscan Reader in Tropical Forestry, ed. Rietbergen, London: Earthscan Publications Ltd. 
Prestemon, J. 2000. Public Open Access and Private Timber Harvests: Theory and Application to the Effects of Trade Liberalization in Mexico. Environmental and Resource Economics 17, 311-34.

Sutinen, J. and P. Andersen. 1985. The Economics of Fisheries Law Enforcement. Land Economics 61(4), 387-397.

Vincent, J. 1990. Rent Capture and the Feasibility of Tropical Forest Management. Land Economics 66, 212-23.

Walker, R. and T. Smith 1993. Tropical Deforestation and Forest Management under the System of Concession Logging: A Decision-Theoretic Analysis. Journal of Regional Science 33, 387-419.

Varian, H.-R. 1992. Microeconomic Analysis, 3rd edition, W.W. Norton \& Company, New York.

Veríssimo, A, Cochrane, M., and Souza, C. 2002. National Forests in the Amazon. Science 297:1478.

Yitzhaki, S. 1974. A Note on Income Tax Evasion: A Theoretical Analysis, Journal of Public Economics 3, 201-202. 


\section{CESifo Working Paper Series}

(for full list see www.cesifo.de)

1066 Christian Keuschnigg, Public Policy and Venture Capital Backed Innovation, October 2003

1067 Thomas von Ungern-Sternberg, State Intervention on the Market for Natural Damage Insurance in Europe, October 2003

1068 Mark V. Pauly, Time, Risk, Precommitment, and Adverse Selection in Competitive Insurance Markets, October 2003

1069 Wolfgang Ochel, Decentralising Wage Bargaining in Germany - A Way to Increase Employment?, November 2003

1070 Jay Pil Choi, Patent Pools and Cross-Licensing in the Shadow of Patent Litigation, November 2003

1071 Martin Peitz and Patrick Waelbroeck, Piracy of Digital Products: A Critical Review of the Economics Literature, November 2003

1072 George Economides, Jim Malley, Apostolis Philippopoulos, and Ulrich Woitek, Electoral Uncertainty, Fiscal Policies \& Growth: Theory and Evidence from Germany, the UK and the US, November 2003

1073 Robert S. Chirinko and Julie Ann Elston, Finance, Control, and Profitability: The Influence of German Banks, November 2003

1074 Wolfgang Eggert and Martin Kolmar, The Taxation of Financial Capital under Asymmetric Information and the Tax-Competition Paradox, November 2003

1075 Amihai Glazer, Vesa Kanniainen, and Panu Poutvaara, Income Taxes, Property Values, and Migration, November 2003

1076 Jonas Agell, Why are Small Firms Different? Managers' Views, November 2003

1077 Rafael Lalive, Social Interactions in Unemployment, November 2003

1078 Jean Pisani-Ferry, The Surprising French Employment Performance: What Lessons?, November 2003

1079 Josef Falkinger, Attention, Economies, November 2003

1080 Andreas Haufler and Michael Pflüger, Market Structure and the Taxation of International Trade, November 2003

1081 Jonas Agell and Helge Bennmarker, Endogenous Wage Rigidity, November 2003 
1082 Fwu-Ranq Chang, On the Elasticities of Harvesting Rules, November 2003

1083 Lars P. Feld and Gebhard Kirchgässner, The Role of Direct Democracy in the European Union, November 2003

1084 Helge Berger, Jakob de Haan and Robert Inklaar, Restructuring the ECB, November 2003

1085 Lorenzo Forni and Raffaela Giordano, Employment in the Public Sector, November 2003

1086 Ann-Sofie Kolm and Birthe Larsen, Wages, Unemployment, and the Underground Economy, November 2003

1087 Lars P. Feld, Gebhard Kirchgässner, and Christoph A. Schaltegger, Decentralized Taxation and the Size of Government: Evidence from Swiss State and Local Governments, November 2003

1088 Arno Riedl and Frans van Winden, Input Versus Output Taxation in an Experimental International Economy, November 2003

1089 Nikolas Müller-Plantenberg, Japan’s Imbalance of Payments, November 2003

1090 Jan K. Brueckner, Transport Subsidies, System Choice, and Urban Sprawl, November 2003

1091 Herwig Immervoll and Cathal O'Donoghue, Employment Transitions in 13 European Countries. Levels, Distributions and Determining Factors of Net Replacement Rates, November 2003

1092 Nabil I. Al-Najjar, Luca Anderlini \& Leonardo Felli, Undescribable Events, November 2003

1093 Jakob de Haan, Helge Berger and David-Jan Jansen, The End of the Stability and Growth Pact?, December 2003

1094 Christian Keuschnigg and Soren Bo Nielsen, Taxes and Venture Capital Support, December 2003

1095 Josse Delfgaauw and Robert Dur, From Public Monopsony to Competitive Market. More Efficiency but Higher Prices, December 2003

1096 Clemens Fuest and Thomas Hemmelgarn, Corporate Tax Policy, Foreign Firm Ownership and Thin Capitalization, December 2003

1097 Laszlo Goerke, Tax Progressivity and Tax Evasion, December 2003

1098 Luis H. B. Braido, Insurance and Incentives in Sharecropping, December 2003 
1099 Josse Delfgaauw and Robert Dur, Signaling and Screening of Workers' Motivation, December 2003

1100 Ilko Naaborg, Bert Scholtens, Jakob de Haan, Hanneke Bol and Ralph de Haas, How Important are Foreign Banks in the Financial Development of European Transition Countries?, December 2003

1101 Lawrence M. Kahn, Sports League Expansion and Economic Efficiency: Monopoly Can Enhance Consumer Welfare, December 2003

1102 Laszlo Goerke and Wolfgang Eggert, Fiscal Policy, Economic Integration and Unemployment, December 2003

1103 Nzinga Broussard, Ralph Chami and Gregory D. Hess, (Why) Do Self-Employed Parents Have More Children?, December 2003

1104 Christian Schultz, Information, Polarization and Delegation in Democracy, December 2003

1105 Daniel Haile, Abdolkarim Sadrieh and Harrie A. A. Verbon, Self-Serving Dictators and Economic Growth, December 2003

1106 Panu Poutvaara and Tuomas Takalo, Candidate Quality, December 2003

1107 Peter Friedrich, Joanna Gwiazda and Chang Woon Nam, Development of Local Public Finance in Europe, December 2003

1108 Silke Uebelmesser, Harmonisation of Old-Age Security Within the European Union, December 2003

1109 Stephen Nickell, Employment and Taxes, December 2003

1110 Stephan Sauer and Jan-Egbert Sturm, Using Taylor Rules to Understand ECB Monetary Policy, December 2003

1111 Sascha O. Becker and Mathias Hoffmann, Intra-and International Risk-Sharing in the Short Run and the Long Run, December 2003

1112 George W. Evans and Seppo Honkapohja, The E-Correspondence Principle, January 2004

1113 Volker Nitsch, Have a Break, Have a ... National Currency: When Do Monetary Unions Fall Apart?, January 2004

1114 Panu Poutvaara, Educating Europe, January 2004

1115 Torsten Persson, Gerard Roland, and Guido Tabellini, How Do Electoral Rules Shape Party Structures, Government Coalitions, and Economic Policies? January 2004

1116 Florian Baumann, Volker Meier, and Martin Werding, Transferable Ageing Provisions in Individual Health Insurance Contracts, January 2004 
1117 Gianmarco I.P. Ottaviano and Giovanni Peri, The Economic Value of Cultural Diversity: Evidence from US Cities, January 2004

1118 Thorvaldur Gylfason, Monetary and Fiscal Management, Finance, and Growth, January 2004

1119 Hans Degryse and Steven Ongena, The Impact of Competition on Bank Orientation and Specialization, January 2004

1120 Piotr Wdowinski, Determinants of Country Beta Risk in Poland, January 2004

1121 Margarita Katsimi and Thomas Moutos, Inequality and Redistribution via the Public Provision of Private Goods, January 2004

1122 Martin Peitz and Patrick Waelbroeck, The Effect of Internet Piracy on CD Sales: CrossSection Evidence, January 2004

1123 Ansgar Belke and Friedrich Schneider, Privatization in Austria: Some Theoretical Reasons and First Results About the Privatization Proceeds, January 2004

1124 Chang Woon Nam and Doina Maria Radulescu, Does Debt Maturity Matter for Investment Decisions?, February 2004

1125 Tomer Blumkin and Efraim Sadka, Minimum Wage with Optimal Income Taxation, February 2004

1126 David Parker, The UK's Privatisation Experiment: The Passage of Time Permits a Sober Assessment, February 2004

1127 Henrik Christoffersen and Martin Paldam, Privatization in Denmark, 1980-2002, February 2004

1128 Gregory S. Amacher, Erkki Koskela and Markku Ollikainen, Deforestation, Production Intensity and Land Use under Insecure Property Rights, February 2004

1129 Yin-Wong Cheung, Javier Gardeazabal, and Jesús Vázquez, Exchange Rate Dynamics: Where is the Saddle Path?, February 2004

1130 Alberto Alesina and Guido Tabellini, Bureaucrats or Politicians?, February 2004

1131 Gregory S. Amacher, Erkki Koskela, and Markku Ollikainen, Socially Optimal Royalty Design and Illegal Logging under Alternative Penalty Schemes, February 2004 